\title{
Accounting
}

\section{A study on the financial soundness of Indian automobile industries using Altman Z-Score}

\section{M. Swalih ${ }^{a}$, K.B. Adarsh ${ }^{b}$ and M.M. Sulphey ${ }^{c^{*}}$}

${ }^{a}$ Research Scholar, Department of Commerce, University of Kerala, India

${ }^{b}$ Research Scholar, Government College for Women, Trivandrum, India

cProfessor, Prince Sattam Bin Abdulaziz University, Saudi Arabia

\section{H R O N I C L E \\ A B S T R A C T}

Article history:

Received: October 10, 2020

Received in revised format:

November 282020

Accepted: December 4, 2020

Available online:

December 4, 2020

Keywords:

Altman Z score

Automobile Industry

Financial Soundness

Bankruptcy
Altman Z score is an effective tool for measuring a company's financial strength and the possibility of bankruptcy. In this study, the $Z$ score formula was utilized to measure the Indian automobile industry's financial soundness. The financial data of ten automobile companies listed in the National Stoke Exchange (NSE) was taken to analyze both original and emerging market formulae of the Altman Z score. Results suggest that companies of the industry listed in the NSE are financially sound. The study concluded that the Indian automobile industry is sound and robust, and the automobile companies are not prone to financial distress or bankruptcy in the near future.

\section{Introduction}

The Indian automotive industry is one of the largest in the world. It contributes 7.1\% towards the Gross Domestic Product (GDP) of the country. Domestic automobiles production increased at 2.36 percent CAGR between FY16-20, with 26.36 million vehicles being manufactured in the country in FY20 (Investindia, 2019). Due to the rising middle class and the young population, the twowheeler segment dominates the industry in terms of volume. Besides, companies' growing interest in developing rural markets further contributed to the growth of the sector. Two-wheelers and passenger cars accounted for $80.8 \%$ and $12.9 \%$ of the market share, respectively, with combined sales of more than 20.1 million vehicles in the FY20 (Ibef, 2020). India is also a leading auto exporter and has strong prospects for export growth shortly. Besides, multiple initiatives by the Government of India and leading automobile players on the Indian market are projected to make India the world's largest two-wheeler and four-wheeler market by 2020. Automobile exports crossed 4.77 million vehicles in FY20, growing at a CAGR of 6.94 percent during FY16-FY20. Twowheelers accounted for 73.9 percent of the vehicles exported, followed by 14.2 percent for passenger vehicles, 10.5 percent for three-wheelers, and 1.3 percent for commercial vehicles (Ibef, 2020). According to the data released by the Department for Promotion of Industry and Internal Trade (DPIIT), the industry has attracted Foreign Direct Investment (FDI) worth US\$ 24.21 billion between April 2000 and March 2020. However, despite the increase in exports, foreign direct investments, and automobile manufacturing, the recent economic downturn, and the covid-19 pandemic outbreak have impacted the sales, potentially affecting the companies' financial health. The bankruptcy of a company poses a risk to both equity and bondholders. While there are steps such as fundamental analysis to calculate efficiency and ratio analysis to assess companies' financial soundness, this is not adequate

* Corresponding author.

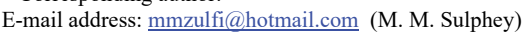


to estimate the probability of bankruptcy or financial distress. The current situation demands a useful tool for a more accurate evaluation of financial soundness. Altman $\mathrm{Z}$ score is such a tool that predicts potential financial distress, thereby estimating the companies' health. Hence, this study focuses on the bankruptcy prediction phenomenon of selected automobile companies listed on the National Stock Exchange, using the Altman Z score.

\subsection{Review of Literature}

Several studies have been conducted over the years on the financial performance and financial soundness of the Indian automobile industry using different financial tools such as profitability ratios, leverage ratios, liquidity ratios, etc. One such study was done by Ranjithkumar and Eahambaram (2018), who studied the determinants of the financial performance of the automobile industry in India and tried to ascertain the impact of economic performance on profitability and liquidity positions of the select companies. They concluded that liquidity has a significant role in automobile companies' financial performance and it is vital to maintain an adequate liquidity position to avoid dire circumstances. Jethwa (2015) evaluated the operating leverage of automobile companies listed in Nifty 50. A study of similar nature was done by Jothi and Geethalakshmi (2017), who tried to evaluate the profitability \& financial position of selected companies in the Indian automobile industry using statistical tools like ratio analysis, mean, standard deviation, correlation. While financial ratios such as profitability ratios, liquidity ratios, and leverage ratios are an effective measure of companies' financial soundness, a more comprehensive tool is Altman Z score, a combination of profitability, leverage, solvency, and liquidity, and activity ratios (Altman, 1968). Several studies have been done in India using the Altman Z score. Raj and Dinakar (2017) analyzed selected automobile companies' financial performance using the Altman Z score. They found that the automobile industry's financial health is good and says that the Altman Z score is an excellent tool to analyze the financial stability of a company. Other studies on Altman Z score in India include Bandyopadhyay (2006), Sulphey and Nisa (2013), and Swalih and Vinod (2017). Bandyopadhyay (2006) tried to develop a Z score model to predict corporate default in the economy. He concluded that both financial and non-financial factors must be included in default prediction models, rather than accounting ratios. Sulphey and Nisa (2013) assessed the solvency position of 220 BSE-Small Cap companies, while Swalih and Vinod (2017) studied the financial performance of BSE Greenex companies using the Altman Z Score.

\subsection{Altman Z-Score}

Attaining financial soundness is very important for the development of any business. A company's ability to settle payments timely, finance its operations adequately and withstand contingencies determine its financial soundness. There are many ways to measure or indicate the financial wellness of a business. Financial ratios such as current liquidity ratio and owners' equity to total assets ratio are effective methods to evaluate Lace's financial soundness (2010). Altman (1968) developed a bankruptcy prediction model called the Altman Z-score model, also called a multiple discriminant analysis model (MDA). This is a multivariate model using a linear combination of four or five financial ratios weighted by coefficients. It is a highly useful formula that has gained wide acceptance with various stakeholders like investors, financial analysts, consultants, bankers, auditors, management accountants, financial institutions, courts, and database systems. A z-score model is a diagnostic tool for financial health and soundness with a high level of accuracy, which can predict $94 \%$ correctly for one year before bankruptcy occurs; and $72 \%$ two years before its actual occurrence Altman (2003). This has been further highlighted by studies such as Permatasari (2006) and Molina (2005). The original model was for manufacturing companies only. Therefore, he developed a model for nonmanufacturing firms. He also developed a model to accommodate the situations in an emerging market, which can have a different environment than a developed economy (Altman, 1993). He further revised his model in 1983 to accommodate smaller private firms.

\subsection{Objectives}

- Assess the financial soundness of the Indian automobile industry.

- Help investors identify healthy companies.

\section{Research Methodology}

Selected automobile companies, representative of all segments such as tractors, trucks, LCVs, passenger cars, two and threewheelers, listed in the National Stock Exchange (NSE), were analyzed to study the Indian automobile industry's financial soundness. The annual financial data from the select companies' financial statements during the FY 2019-2020 was used to compute the Altman Z-score of the industry. The study was done using a financial tool developed by Altman in 1968. The multivariate model, namely Altman Z-score, is a combination of five weighted variables, which utilizes profitability, leverage, solvency, liquidity, and activity to understand firms' financial health. Altman developed and revised his original formula according to changing needs. Two Altman Z score models have been used for the study, the original model for manufacturing companies and the revised model for emerging markets. 
The original formula developed for public manufacturing companies is as follows;

Model 1: $Z=1.2 \times X_{1}+1.4 \times X_{2}+3.3 \times X_{3}+0.6 \times X_{4}+0.999 \times X_{5}$.

where, $\mathrm{X}_{1}=$ Working Capital / Total Assets

$\mathrm{X}_{2}=$ Retained Earnings / Total Assets

$\mathrm{X}_{3}=$ Earnings Before Interest and Taxes / Total Assets

$\mathrm{X}_{4}=$ Market Value of Equity / Total Liabilities

$\mathrm{X}_{5}=$ Net Sales $/$ Total Assets
The Interpretation of the Z-Score Model:

$$
\begin{gathered}
\text { Z score }>2.99 \text { means "Safe" Zones } \\
1.81<Z \text { score }<2.99 \text { means "Grey" Zones } \\
Z \text { score }<1.81 \text { means "Distress" Zones }
\end{gathered}
$$

For a more accurate evaluation of the industry's financial health, the revised Z-score model for emerging markets was also computed. It is a four-variable model with a constant. The formula is as follows:

Model $2: \mathrm{Z}=3.25+6.56 \times \mathrm{X} 1+3.26 \times \mathrm{X} 2+\mathrm{X} 3+6.72 \times \mathrm{X} 3+1.05 \times \mathrm{X} 4$.

where, $\mathrm{X}_{1}=$ Working Capital / Total Assets

$\mathrm{X}_{2}=$ Retained Earnings / Total Assets

$\mathrm{X}_{3}=$ Earnings Before Interest and Taxes / Total Assets

$\mathrm{X}_{4}=$ Book Value of Equity / Total Liabilities
The Interpretation of Emerging Market Score Model:

EM Z score $>2.60$ means "Safe" Zones

$1.1<$ EM Z score $<2.60$ means "Grey" Zones

EM Z score $<1.1$ means "Distress" Zones

\section{Analysis and Interpretations}

Financial data of ten automobile companies listed in the National Stock Exchange was used to study the industry's financial health using the Altman $\mathrm{Z}$ score. Both the original model, as well as the Emerging market model, was utilized to analyze the data.

\begin{tabular}{|c|c|c|c|c|c|c|c|c|}
\hline Company & $\begin{array}{c}\text { Total } \\
\text { Assets }\end{array}$ & $\begin{array}{c}\text { Working } \\
\text { Capital }\end{array}$ & $\begin{array}{l}\text { Retained } \\
\text { Earnings }\end{array}$ & EBIT & $\begin{array}{c}\text { Market } \\
\text { Value }\end{array}$ & $\begin{array}{l}\text { Book } \\
\text { Value }\end{array}$ & Total Liabilities & Sales \\
\hline Ashok & 16389.61 & -1575.44 & 6970.44 & 627.2 & 14281.34 & 7265.429 & 16389.61 & 17467.47 \\
\hline Eicher & 10579.01 & 4475.48 & 8248.04 & 2441.2 & 56354.95 & 8274.39 & 10579.01 & 9077.47 \\
\hline Escorts & 5312.08 & 1134.56 & 3357.5 & 663.52 & 15290.24 & 3493.561 & 5312.08 & 5760.95 \\
\hline Hero & 18749.33 & 4312.5 & 14081.01 & 3918.34 & 53460.69 & 14123.04 & 18749.33 & 28836.09 \\
\hline Mahindra & 50502.06 & 4168.67 & 33871.32 & 5243.24 & 75393.41 & 34492.38 & 50502.06 & 45487.78 \\
\hline Force & 3106.54 & 110.57 & 1962.53 & 116.74 & 1190.41 & 1975.70 & 3106.54 & 3080.13 \\
\hline Maruti & 62552.1 & -2867.4 & 48286 & 7197.7 & 189185.19 & 48437.02 & 62552.1 & 75610.6 \\
\hline Tata & 62589.87 & -12242.06 & 17668.11 & -2643.42 & 32326.11 & 18286.72 & 62589.87 & 43485.76 \\
\hline TVS & 9361.16 & -1281.77 & 3570.58 & 888.93 & 18409.63 & 3618.26 & 9361.16 & 16423.34 \\
\hline Bajaj & 24773.3 & 2343.75 & 19636.12 & 6583.36 & 86953.34 & 19908.37 & 24773.3 & 29918.65 \\
\hline
\end{tabular}

Table 1

Data of Indian Automobile Companies

Data for the Financial Year 2019-2020 retrieved from Moneycontrol.com was analyzed to evaluate the financial soundness of the select companies and the Z-Score derived is as follows:

\begin{tabular}{|c|c|c|c|c|c|}
\hline Company & Original Z score & $\begin{array}{c}\text { Emerging Market Z } \\
\text { Score }\end{array}$ & Company & $\begin{array}{c}\text { Original } \mathbf{Z} \\
\text { score }\end{array}$ & $\begin{array}{c}\text { Emerging Market } \mathbf{Z} \\
\text { Score }\end{array}$ \\
\hline Ashok Leyland & 2.19 & 4.72 & Mahindra\& Mahindra & 3.17 & 7.39 \\
\hline Eicher Motors & 6.41 & 10.93 & Force Motors & 2.27 & 6.46 \\
\hline Escorts Ltd & 4.36 & 8.24 & Maruti Suzuki & 4.42 & 7.05 \\
\hline Hero MotoCorp & 5.26 & 9.40 & Tata Motors & 1.02 & 2.91 \\
\hline TVS Motors & 3.61 & 4.63 & Bajaj Auto & 5.41 & 9.08 \\
\hline Average Z-Score & 3.81 & 7.08 & & & \\
\hline
\end{tabular}

Table 2

Z-Score values

According to Altman Z Score Models, the interpretation of the values are made in the following manner;

\begin{tabular}{|c|c|c|}
\hline Z-Score Model & Values & Interpretation \\
\hline \multirow{3}{*}{ Original Model } & Less than 1.81 & Distress Zone \\
\hline & 1.81 to 2.99 & Grey Zone \\
\hline & Above 2.99 & Safe Zone \\
\hline \multirow{3}{*}{ Emerging Market Model } & Less than 1.1 & Distress Zone \\
\hline & 1.1 to 2.6 & Grey Zone \\
\hline & Above 2.6 & Safe Zone \\
\hline
\end{tabular}

Table 3

Interpretation of Z-Score 
Table 2 shows that most companies in the automobile industry are in the safe zone in both models of Z-score. Eight companies fall in the original model's safe zone, one company in the grey zone, and one in the distress zone. In the Emerging market model, we see that all the companies are in the safe zone. The highest $\mathrm{Z}$ score in both models is for Eicher Motors, while Tata Motors has the least Z-score value.

\section{Conclusion}

Analyzing the Atman Z-Score of the Indian automobile industry, we have concluded that the industry is very robust and healthy. The companies of the industry listed in the NSE are financially sound. Companies such as Eicher Motors, Hero Moto Corp, and Bajaj Auto outperform others in the industry. Both institutional and individual investors should invest in the Indian automobile industry, as the companies are not prone to bankruptcy or financial distress in the near future. The original formula and the emerging market formula are to be studied in a growing economy like India to evaluate the z-score values more accurately. Altman Z-score is a highly useful model to analyze companies' financial soundness and is recommended to investors and financial analysts to evaluate the financial health of firms and make decisions regarding the same.

\section{References}

Dharmaraj, A. \& Kathirvel, N. (2013). Financial performance of Indian automobile industry -A comparative study during pre and post foreign direct investment. Ijsr - International Journal Of Scientific Research, 2(9), 54-56.

Altman, E. I. (1983). Bankruptcy cost and the new code. Journal of American Finance Association, 38(2), 517-522.

Altman, E. I. (1968). Financial ratios, discriminant analysis and the prediction of corporate bankruptcy. Journal of Finance, 23(4), 598-608.

Bandyopadhyay, A. (2006). Predicting probability of default of Indian corporate bonds: logistic and Z-score model approaches. Journal of Risk finance, 7, 255-272.

Erlina, P. S. (2006). Analisis kebangkrutan perusahaan telekomunikasi di Indonesia menggunakan model Zmijewski (X-score) and model Altman (Z-score). Undergraduate Thesis, Universitas Negeri Malang.

Ibef. (2020, June). Indian Automobile Industry Report. Retrieved August 17, 2020, from ibef.org/industry: https://www.ibef.org/industry/india-automobiles.aspx

Investindia. (2019). Iinvestindia.gov.in/sector/automobile. Retrieved August 17, 2020, from Investindia.gov.in: https://www.investindia.gov.in/sector/automobile

Jethwa, D. (2015). A study on operating leverage of Indian automobile companies from Nifty 50. EPRA International Journal of Economic and Business Review, 3(4), 145-147.

Jothi, K. \& Geethalakshmi.A. (2017). An Insight into the Performance of Indian Automobile Industry. Science Education Development Institute, 2(5), 191-197.

Lace, N., \& Sundukova., Z. (2010). Company’s standards for financial soundness indicators. Business And Management, 112117.

Prathibha, M. S., \& Dinakar.G. (2017). Analysis of selected automobile companies in India by using altamin Z score. BIMS International Journal of Social Science Research, 2(1), 37-54.

Ranjithkumar, M.S. \& Eahambaram, C. (2018). A study on profitability analysis of Indian selected automobile industry in India. International Journal for Research in Engineering Application \& Management, 2(7), 412-416.

Molina, A.C. (2005). Are firms underleveraged? An examination of the effect of leverage on default probabilities. Journal of Finance, 60(3), 1427-1459.

Moneycontrol. (n.d.). Retrieved August 17, 2020, from https://www.moneycontrol.com/

Permatasari, I. R. (2006). Pengaruh Pengembangan Karir terhadap kinerja Karyawan (Studi Kasus di PT. Telkom Malang). Jurnal Ekonomi Modernisasi, 2(3), 177-191.

Sulphey, M. M., \& Nisa.S. (2013). The analytical implication of Altman's Z score analysis of BSE listed small cap companies. Global Journal of Commerce \& Management Perspective, 2(4), 145-155.

Swalih, M. M., \& Vinod. M. S, (2017). Application of Altman Z score on Bse-Greenex companies. Journal of Applied Management and Investments, 6(3), 205-215.

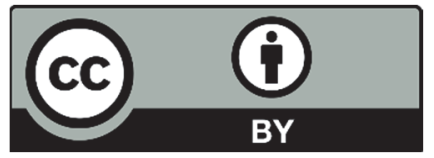

(C) 2021 by the authors; licensee Growing Science, Canada. This is an open access article distributed under the terms and conditions of the Creative Commons Attribution (CC-BY) license (http://creativecommons.org/licenses/by/4.0/). 